\title{
Stem cells for lung cancer: impacts and future developments
}

\author{
Francesco Petrella ${ }^{1,2}$ \\ ${ }^{1}$ Department of Thoracic Surgery, IRCCS European Institute of Oncology, Milan, Italy; ${ }^{2}$ Department of Oncology and Hemato-oncology, \\ University of Milan, Milan, Italy \\ Correspondence to: Francesco Petrella, MD, PhD. Department of Thoracic Surgery, European Institute of Oncology, Via Ripamonti, 435, Milan, Italy; \\ Department of Oncology and Hemato-oncology, University of Milan, Milan 20141, Italy. Email: francesco.petrella@ieo.it; \\ francesco.petrella@unimi.it.
}

Received: 26 April 2019; Accepted: 05 August 2019; Published: 16 August 2019.

doi: 10.21037/shc.2019.08.01

View this article at: http://dx.doi.org/10.21037/shc.2019.08.01

Malignant pulmonary neoplasms are the most frequent cause of cancer-related death worldwide (1), accounting for more than 1.8 million newly diagnosed cancers and 1.6 million cancer-related deaths worldwide every year (2).

The whole amount of regulatory modifications leading to cancer development can originate from prolonged exposure to tobacco smoke, thus causing structural damages that can express as chronic obstructive pulmonary disease (COPD). Continuous smoke and environmental pollutants exposure can result into a well-defined series of structural modifications of the bronchial epithelium of the airway, ranging from basal cell hyperplasia to metaplasia, severe dysplasia and finally carcinoma (3).

A wide spectrum of primary lung tumors with several biological peculiarities exist, ranging from almost indolent and effectively treatable disease to highly aggressive lesions characterized by poor prognosis; nowadays it is mandatory to have a biological knowledge of lung tumors, particularly in advanced stage where local control by surgery and radiotherapy is not effective.

Considering that only a small amount of lung cancer patients can be diagnosed at an early stage, thus having a good prognosis and many effective treatments to be offered, exploration of new frontiers is constantly required.

Stem cells are cells that can differentiate into other types of cells, and can also divide in self-renewal to produce more of the same type of stem cells (4).

Mesenchymal stem cells_-also defined as stromal cellsare undifferentiated cells presenting properties of selfrenewal and the potential to differentiate in vitro and in vivo into a wide spectrum of cells, like chondrogenic, osteogenic and adipogenic lineages when cultured in specific inducing culture media (4).

There are at least two types of stem cells: embryonic stem cells (EC), arising from the inner cell mass of blastocysts, and adult stem cells (AC), deriving from several tissues, like adipose tissue, blood, bone marrow and other sources (5). Many researchers have studied potential clinical applications of stem cells in several medical specialtiesincluding thoracic surgery-although with controversial and still unclear results (6).

Two major aspects of potential application in clinical daily practice of stem cells in cardio-thoracic surgery have been studied: (I) regenerative and reparative medicine, representing a part of biomedical research in molecular biology as well as in tissue engineering, focusing on the possibility of replacing, engineering or regenerating of organs, tissues and cells to restore normal physiology; (II) drug-loading and drug-delivery, that is a new science branch, studying how stem cells may serve as vectors to deliver anti-neoplastic compounds for oncologic therapies (7). Mesenchymal stromal cells (MSC) disclosed the ability to accumulate within the cell and to release deliver many antineoplastic drugs, without any modifications of the cellular genome, thereby reducing tumor progression (8). Non-modified MSC are one of the most intriguing tools for antineoplastic drug delivery; in fact they can adapt to culture characteristics and target neoplastic sites when injected in vivo (8). MSC present several properties: first, they produce active soluble factors playing an active immune role; moreover they can pass through the blood brain barrier: for this reason they can be considered an appealing potential 
tool for adult and pediatric cerebral tumors; on the contrary the aspect of whether MSC interacting with the tumor environment boost tumor suppression or instead favor tumor growth remains unclear (9); they can uptake and deliver-to target tissue-antineoplastic drugs both as free molecule and exosome associated drugs (10).

We have previously reported that bone marrow-derived MSC primed with paclitaxel—an anticancer drug targeting tubulin and stabilizing the microtubule polymer protecting it from disassembly-effectively block in vitro proliferation of malignant mesothelioma cells (11). However further experiments are required to confirm our initial in vitro results and to extend them to lung cancer therapy.

Although some concerns about safety of stem cell application in oncologic field have been reported (12), there are no definitive data about this aspect that should be further assessed (13).

\section{Acknowledgments}

Funding: None.

\section{Footnote}

Provenance and Peer Review: This article was commissioned by the Guest Editors (Giulia Sedda and Roberto Gasparri) for the series "A New Era in Lung Cancer Care: from Early Diagnosis to Personalized Treatment" published in Shanghai Chest. The article did not undergo external peer review.

Conflicts of Interest: The author has completed the ICMJE uniform disclosure form (available at http://dx.doi. org/10.21037/shc.2019.08.01). The series "A New Era in Lung Cancer Care: from Early Diagnosis to Personalized Treatment" was commissioned by the editorial office without any funding or sponsorship. FP serves as an unpaid editorial board member of Shanghai Chest from Jun 2018 to May 2020. The author has no other conflicts of interest to declare.

Ethical Statement: The author is accountable for all aspects of the work in ensuring that questions related to the accuracy or integrity of any part of the work are appropriately investigated and resolved.
Open Access Statement: This is an Open Access article distributed in accordance with the Creative Commons Attribution-NonCommercial-NoDerivs 4.0 International License (CC BY-NC-ND 4.0), which permits the noncommercial replication and distribution of the article with the strict proviso that no changes or edits are made and the original work is properly cited (including links to both the formal publication through the relevant DOI and the license). See: https://creativecommons.org/licenses/by-nc-nd/4.0/.

\section{References}

1. Ferlay J, Soerjomataram I, Dikshit R, et al. Cancer incidence and mortality worldwide: sources, methods and major patterns in GLOBOCAN 2012. Int J Cancer 2015;136:E359-86.

2. Gridelli C, Rossi A, Carbone DP, et al. Non-small-cell lung cancer. Nat Rev Dis Primers 2015;1:15009.

3. Colby TV, Wistuba II, Gazdar A. Precursors to pulmonary neoplasia. Adv Anat Pathol 1998;5:205-15.

4. Pittenger MF, Mackay AM, Beck SC, et al. Multilineage potential of adult human mesenchymal stem cells. Science 1999;284:143-7.

5. Kern S, Eichler H, Stoeve J, et al. Comparative analysis of mesenchymal stem cells from bone marrow, umbilical cord blood, or adipose tissue. Stem Cells 2006;24:1294-301.

6. Petrella F. Regenerative medicine in cardiothoracic surgery: do the benefits outweigh the risks? J Thorac Dis 2018;10:S2309-11.

7. Petrella F, Spaggiari L. Stem Cells Application in Thoracic Surgery: Current Perspective and Future Directions. Adv Exp Med Biol 2018;1089:143-7.

8. Pessina A, Bonomi A, Coccè V, et al. Mesenchymal stromal cells primed with paclitaxel provide a new approach for cancer therapy. PLoS One 2011;6:e28321.

9. Pacioni S, D'Alessandris QG, Giannetti S, et al. Human mesenchymal stromal cells inhibit tumor growth in orthotopic glioblastoma xenografts. Stem Cell Res Ther 2017;8:53.

10. Rimoldi I, Coccè V, Facchetti G, et al. Uptake-release by MSCs of a cationic platinum(II) complex active in vitro on human malignant cancer cell lines. Biomed Pharmacother 2018;108:111-8.

11. Petrella F, Coccè V, Masia C, et al. Paclitaxel-releasing mesenchymal stromal cells inhibit in vitro proliferation 
of human mesothelioma cells. Biomed Pharmacother 2017;87:755-8.

12. Spartalis E, Moris D, Dimitroulis D, et al. Postresectional Airway Fistula Occlusion via Stem-Cell Transplantation: Is

doi: $10.21037 /$ shc.2019.08.01

Cite this article as: Petrella F. Stem cells for lung cancer: impacts and future developments. Shanghai Chest 2019;3:44.
It Oncologically Safe? Ann Thorac Surg 2015;100:2413-4.

13. Petrella F, Spaggiari L. Reply: To PMID 24370201. Ann Thorac Surg 2015;100:2414. 